\title{
Effect of environmental contaminants on the health of Mytilus edulis from Puget Sound, Washington, USA. I. Cytochemical measures of lysosomal responses in the digestive cells using automatic image analysis
}

\author{
P. K. Krishnakumar ${ }^{1,2}$, E. Casillas ${ }^{2, *}$, U. Varanasi ${ }^{2}$ \\ ${ }^{1}$ Central Marine Fisheries Institute, PO Box 2704, Cochin 682 031, Kerala, India \\ ${ }^{2}$ Environmental Conservation Division, Northwest Fisheries Science Center, National Marine Fisheries Service, NOAA, \\ 2725 Montlake Blvd East, Seattle, Washington 98112, USA
}

\begin{abstract}
Lysosomal responses in the digestive cells of Mytilus edulis from 9 sites in Puget Sound, Washington, USA, with varying degrees of sediment contamination were measured using automatic image analysis. Mussels from urban-associated sites (areas with elevated sediment concentration of anthropogenic contaminants such as PAHs, PCBs, DDTs, and toxic elements) showed pathological changes in the lysosomes (reduced lysosomal labilization period, reduced lysosomal stability and increased $\mathrm{N}$-acetyl $\beta$-hexosaminidase activity), enhanced lipofuscin deposition and increased accumulation of lysosomal and cytoplasmic unsaturated neutral lipids. Morphometric measures of growth showed that mussels were generally smaller in size and that somatic tissue weight relative to shell length was lower in mussels from urban-associated sites relative to those from minimally contaminated sites. Highly significant correlations were observed between concentrations of tissue PAH, PCB, and selected toxic elements (measures of anthropogenic exposure) and lysosomal labilization period. Pathological alterations in the lysosomal system of mussels from the urban-associated sites were probably induced by the high tissue concentrations of organic and inorganic contaminants rather than as a result of potential confounding biotic (spawning stress) or abiotic (temperature, salinity and food availability) factors. The results show that cytochemical measurement of lysosomal responses combined with automatic image analysis have the potential to be used as sensitive, accurate and rapid techniques for assessing the biological impact of environmental contaminants in mussels in the near coastal environment.
\end{abstract}

KEY WORDS: Mussels · Lysosomal responses $\cdot$ Growth $\cdot$ Contaminants · Image analysis

\section{INTRODUCTION}

Mussels and other marine bivalves are widely used as sentinel organisms in 'mussel watch' programs (e.g. O'Conner 1992) for indicating levels of pollutants in the coastal marine environment due to their ability to bioaccumulate organic or toxic elements. Although studies with both laboratory-exposed and field-transplanted mussels suggest that pollutants cause toxic

- Addressee for correspondence effects to mussels, the biological effects of chemical contaminants on indigenous mussels or other bivalves are not generally measured. The importance of including biological measurements, preferably in concert with chemical content measurements, in 'mussel watch' programs has, however, recently been emphasized (Bayne et al. 1988, Bayne 1989, Gray 1992).

Mussels accumulate chemical contaminants particularly in the digestive gland. Digestive gland cells are not only involved in digestive and absorptive processes but are also involved in the detoxification and excre- 
tion of contaminants (Livingstone 1991). The lysosomal system in the digestive cells has been identified as a target site for the toxic effects of many environmental xenobiotics (see review by Moore 1991b). Lysosomal responses to cell injury due to contaminant exposure fall into essentially 3 categories: changes in lysosomal contents, changes in fusion events and changes in membrane permeability (Hawkins 1980, Moore $1991 b)$. Cytochemical assessment of lysosomal function has been routinely used in medical research for prenatal diagnosis of inherited enzyme defects and especially of lysosomal storage diseases (Henderson 1983, VanNoorden 1991).

Lysosomal responses in the digestive gland cells after exposure to contaminants can be assessed using cytochemical tests for lysosomal fragility, percent latency of hydrolase activity, as well as neutral lipid and lipofuscin content of the lysosomes (Bitensky et al. 1973, Moore 1988). These biomarkers can be cytochemically assessed on a small portion of tissue by using quantitative micro-densitometry or qualitatively measured using a subjective ranking of photomicrographs (Moore 1988, Krishnakumar et al. 1990). Experimental laboratory studies have shown that lysosomal responses in the digestive cells of bivalve molluscs are sensitive bioindicators of organic contaminants and toxic and essential elements (Lowe et al. 1981, Moore \& Clark 1982, Moore et al. 1985, Pipe \& Moore 1986, Nott \& Moore 1987, Axiak et al. 1988, Moore 1988, 1991b, Cajaraville et al. 1989, Krishnakumar et al. 1990, Winston et al. 1991, Viarengo et al. 1992). However, very few field studies have shown lysosomal responses to be valid bioindicators of exposure to environmental xenobiotics in natural populations of marine bivalves (Moore et al. 1982, Moore 1988, Regoli 1992).

Reductions in the scope for growth (net energy budget) is another major effect of xenobiotics on fieldexposed mussels sampled from contaminated areas (Cappuzzo \& Leavitt 1988, Widdows \& Johnson 1988, Widdows et al. 1990). When mussels from uncontaminated sites are transplanted along known pollution gradients, scope for growth is similarly reduced for mussels that are placed in the most contaminated areas, resulting in reduced growth of these mussels (Martin et al. 1984, Salazar \& Salazar 1991, Veldhuizen-Tsoerkan et al. 1991). However, it has been difficult to demonstrate that the growth of chronically exposed indigenous mussels is in fact reduced. Concerns regarding the influence of other confounding abiotic and bio:ic factors that are known to affect mussel growth have to date prevented the identification of poor growth of resident mussels from contaminated areas, although bioenergetics measurements from field and laboratory studies suggest that impaired growth should occur.
Until recently, it has been difficult to provide quantitative measures of cytochemically based changes in mussels exposed to contaminants. However, the use of image analysis can improve the analysis of cytochemically derived measurements. Computer-assisted image analysis is beginning to be used in clinical and pathological research to provide information regarding cellular and tissue abnormalities (Bartels \& Weid 1981, Hader 1992). This technique allows an easy, rapid and objective analysis of the tissues for diagnostic purpose and the visual demonstration of the results (Dardick \& Payne 1992). However, automatic image analysis (AIA) techniques are not yet routinely used in the qualitative or quantitative diagnosis of cellular or lysosomal responses in marine animals in response to environmental xenobiotics. The purpose of this study, thus, was to use image analysis to measure the lysosomal responses in the digestive cells of Mytilus edulis collected from a number of sites in Puget Sound, Washington, USA, with varying degrees of sediment contamination to demonstrate the applicability of these techniques in a field survey. Lysosomal and biological responses in mussels were then compared between mussels from the minimally contaminated reference and the urbanassociated sites. Relationships among organic contaminant and toxic element body burden, lysosomal responses, and measures of growth were then evaluated to demonstrate linkages between xenobiotic exposure of indigenous mussels in the marine environment and the subsequent cellular and biological effects.

\section{MATERIALS AND METHODS}

Mytilus edulis (L.) were collected from their natural beds from 9 sites in Puget Sound (Fig. 1) during September 21-24, 1992. Sites included the minimally contaminated reference areas of Oak Bay, Coupeville and Double Bluff, in central and north Puget Sound, and Saltwater Park of south Puget Sound. Mussels from these areas were used to document the normal variability for each parameter (described below) measured in this study. Analyses of tissues of mussels sampled from most of these sites during a previous survey showed that chemical contamination was low for these mussels ( $E$. Casillas pers, obs.). By using mussels from a number of reference sites to characterize the normal range for each parameter measured, we hoped to minimize the influence of varying abiotic and biotic factors when comparing mussels from urbanassociated and reference sites. Urban sites that were sampled for mussels included Eagle Harbor, Seacrest and Four Mile Rock in Elliott Bay, City Waterway in Commencement Bay, and Sinclair Inlet. Mussels from 


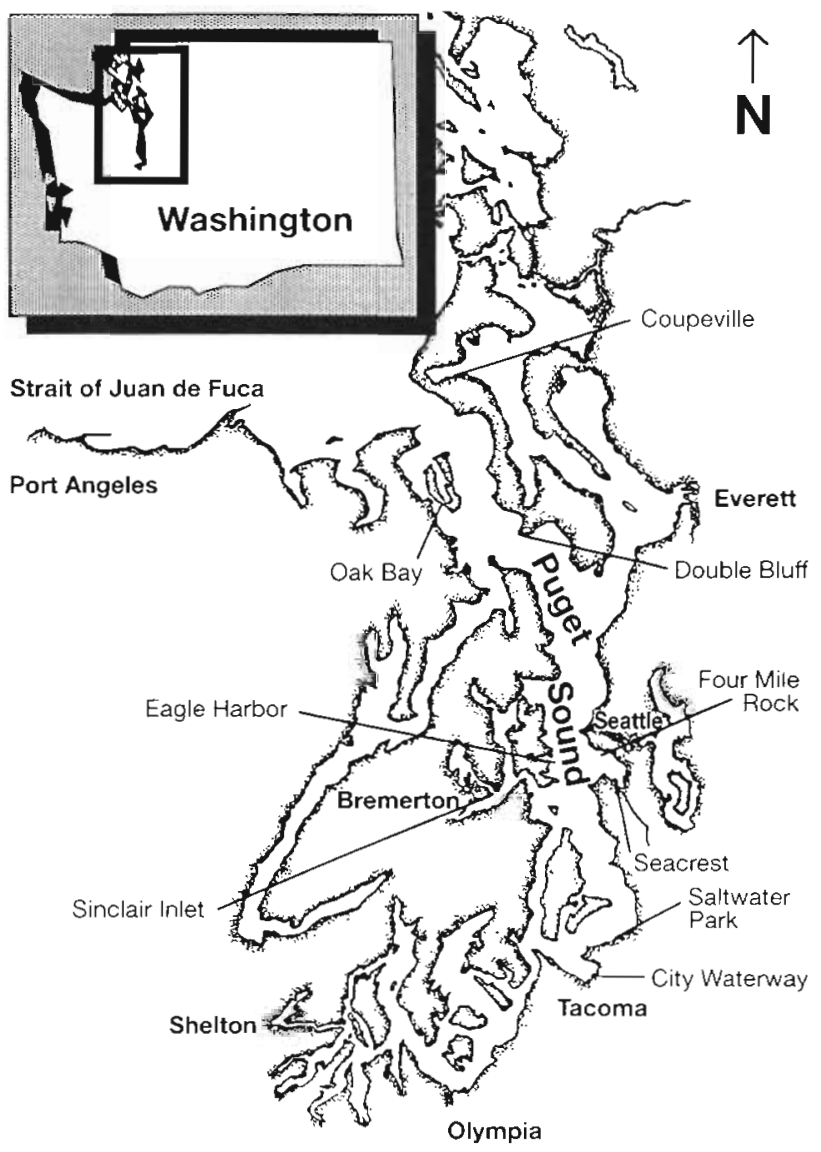

Fig. 1. Collection sites in Puget Sound, Washington, USA

these areas were likely to be chronically exposed to a variety of anthropogenic chemical contaminants. Historically, for example, areas within Eagle Harbor are contaminated with high levels of creosote-associated polycyclic aromatic hydrocarbons (PAHs), and Commencement Bay and Elliott Bay are characterized as high-density urban environments contaminated with a variety of organic and inorganic pollutants (Stein et al. 1992). The site at Four Mile Rock represents one of the sampling areas of the National Status and Trends (NS\&T) Mussel Watch Program (NOAA 1989). Concentration of organic contaminants in mussels from this site have been reported to be among the highest observed in mussels in the U.S. near coastal waters.

Mussels ( $n=100$, shell length $\geq 40 \mathrm{~mm}$ ) were randomly collected from each site during low tide and transported to the laboratory in live condition. Mussels $<40 \mathrm{~mm}$ were excluded because the amount of tissue was insufficient for all the analyses. Water temperature was recorded and water samples were collected from each site to determine salinity and particulate organic matter content. Mussels were acclimated in running seawater for $24 \mathrm{~h}$ to allow the gut contents to be cleared before they were randomly subsampled as described below.

Particulate organic matter (POM) and salinity. Seawater (1 l) from each site was filtered using $35 \mathrm{~mm}$ glass fiber filters to obtain particulate organic matter. The glass fiber filter was dried at $110^{\circ} \mathrm{C}$, weighed and loss of weight on ignition at $450^{\circ} \mathrm{C}$ was determined. The POM content was expressed as $\mathrm{mg} \mathrm{l}^{-1}$. Salinity was determined using a saline refractometer.

Tissue chemistry. Whole mussel tissue samples ( $\mathrm{n}=$ 30 to 40 per site) were dissected out, pooled and kept at $-20^{\circ} \mathrm{C}$ until analysis. Samples were analyzed for organic chemical contaminants as described by MacLeod et al. (1985) and Krahn et al. (1988). Briefly, tissues are homogenized and a portion extracted with methylene chloride, transferred to hexane, and then fractionated using high performance liquid chromatography to isolate aromatic hydrocarbons (AHs), pesticides, polychlorinated biphenyls (PCBs), and polar organic compounds. AHs were quantified using gas chromatography (GC) coupled with mass spectrometry (GC/MS) and chlorinated pesticides and PCBs were determined using GC coupled to an electron capture detector (GC/ECD). Toxic and essential elements in tissues were determined as described in Robisch \& Clark (1993). Briefly, a portion of each tissue homogenate was subjected to strong acid digestion using nitric acid. Toxic element concentrations were then determined using atomic absorption spectophotometry with either air-acetylene flame (zinc), graphite furnace (copper, cadmium, silver, nickel, lead, and arsenic), or cold vapor hydride generation (mercury). The results were expressed in $n g g^{-1}$ dry tissue weight.

Biological measurements. All encrusting organisms and the byssus threads were removed from the mussels subsampled for biological measurements $(n=20)$. The following measurements were made for each mussel from each site: length, whole tissue wet weight and gonad (with mantle) wet weight. Smears taken from gonads were microscopically examined to determine gametogenic phase. Mussels were classified as being in a gametogenic spawning phase or in a nongametogenic resting, nonspawning phase. Gonadal index (GI) was calculated as follows: $\mathrm{GI}=$ (mantle tissue weight/ whole tissue weight) $\times 100$. Dry weight: wet weight ratios were determined from 20 randomly selected mussels. All wet weight measurements were converted to dry weight by multiplying by 0.2 .

Cytochemistry. A small section of digestive gland was rapidly removed from each of 10 randomly selected mussels and placed in straight rows across the center of cryomolds (Tissue-Tek, Miles, Inc., Elkhart, IN, USA) (5 tissue samples mold ${ }^{-1}$ ). Tissue samples 
were quickly embedded in O.C.T compound (TissueTek) and super-cooled in hexane precooled to $-70^{\circ} \mathrm{C}$ in liquid nitrogen. The frozen tissues were sectioned serially at $10 \mu \mathrm{m}$ in a cryostat at $-25^{\circ} \mathrm{C}$. All samples were coded prior to freezing to insure that samples were read blindly and decoded only after all measurements were made.

Neutral lipid: Duplicate sections from each tissue sample were fixed for $10 \mathrm{~min}$ in calcium-formal at $4{ }^{\circ} \mathrm{C}$, rinsed in distilled water and placed in $60 \%$ triethyl phosphate ( $\mathrm{v} / \mathrm{v}$ with distilled water) for $3 \mathrm{~min}$ and stained in a $1 \%$ solution of oil red $O$ in $60 \%$ triethyl phosphate for $15 \mathrm{~min}$ (Bancroft 1967). Sections were washed in $60 \%$ triethyl phosphate for $30 \mathrm{~s}$, rinsed in distilled water and mounted using glycerol gelatin (Sigma Chemicals, St Louis, MO, USA).

Lipofuscin: Duplicate sections for each tissue sample were fixed for $10 \mathrm{~min}$ in calcium-formal at $4^{\circ} \mathrm{C}$, rinsed in distilled water and stained for lipofuscin using the Schmorl reaction (Pearse 1972). Sections were stained for $5 \mathrm{~min}$ in a $1 \%$ ferric chloride and $1 \%$ freshly prepared potassium ferricyanide solution (ratio $3: 1, \mathrm{v} / \mathrm{v}$ ), rinsed in $1 \%$ acetic acid for $1 \mathrm{~min}$, rinsed in distilled water for $1 \mathrm{~min}$ and mounted using glycerol gelatin.

$N$-acetyl $\beta$-hexosaminidase (NAH) activity: Duplicate tissue sections were pretreated for $5 \mathrm{~min}$ at $37^{\circ} \mathrm{C}$ in $0.1 \mathrm{M}$ citrate buffer ( $\mathrm{pH} 4.5$ ) containing $2.5 \% \mathrm{NaCl}$ in order to labilize the lysosomal membrane. Following this treatment, sections were incubated in a solution containing $20 \mathrm{mg}$ napthol AS-BI $\mathrm{N}$-acetyl $\beta$-D-glucosaminide dissolved in $2.5 \mathrm{ml}$ 2-methoxy ethanol and made up to $50 \mathrm{ml}$ with $0.1 \mathrm{M}$ citrate buffer ( $\mathrm{pH} 4.5$ ) containing $2.5 \% \mathrm{NaCl}$ and $3.5 \mathrm{~g}$ of low viscosity polypeptide (Sigma Chemicals) for $20 \mathrm{~min}$ at $37^{\circ} \mathrm{C}$. Sections were then rinsed in $3.0 \% \mathrm{NaCl}$ at $37^{\circ} \mathrm{C}$ for 2 min, transferred to $0.1 \mathrm{M}$ phosphate buffer ( $\mathrm{pH} 7.4$ ) containing $1 \mathrm{mg} \mathrm{ml}^{-1}$ fast violet $\mathrm{B}$ at room temperature for $10 \mathrm{~min}$, fixed for $15 \mathrm{~min}$ in calcium-formal at $4{ }^{\circ} \mathrm{C}$, rinsed in distilled water and mounted using glycerol gelatin.

Labilization period: Multiple sections for each tissue sample were incubated at $37^{\circ} \mathrm{C}$ in $0.1 \mathrm{M}$ citrate buffer (pH 4.5) containing $2.5 \% \mathrm{NaCl}$ for various periods of time in order to labilize the lysosomal membrane (Bitensky et al. 1973, Moore 1988). Labilization times of $0,2,5,10,15,20,25$ and 30 min were applied to the serial sections. Following this treatment, sections were incubated in the reaction medium as above for $\mathrm{NAH}$ and mounted as described above. Labilization period is the time of acid labilization required to fully labilize the responsive fraction of lysosomal hydrolase in the digestive cells (Moore 1988). Labilization periods were assessed using image analysis (described below) to determine the period of maximal enzymatic reaction product intensity for NAH activity associated with lysosomes, as related to increasing time of acid labilization.

Percent latency of NAH activity: The \% latency was determined using the formula described by Moore (1991a): \% NAH latency $=[($ total NAH activity - free $\mathrm{NAH}$ activity)/total NAH activity] $\times 100$. Free $\mathrm{NAH}$ activity was obtained from measurements of $\mathrm{NAH}$ activity on tissue sections that received no pretreatment to labilize the lysosomal membrane. Total NAH activity was obtained from measurements on sections in which the lysosomes were fully labilized.

Image analysis. Tissue sections were quantitatively and objectively assessed for enzymatic activities and neutral lipid and lipofuscin content using computerassisted image analysis. The image analysis system consists of a high resolution CCD color camera (COHU mod. 8215.2000) mounted on a light microscope. The image is displayed on a television screen and captured using an image analysis program (NIH image 1.44) on a Macintosh IIcx microcomputer (Apple, Inc.). The program allows the user to acquire, display, edit, enhance, analyze and print the images. Image intensity was measured using gray values with an arbitrary scale of 0 (clear, white) to 255 (dark, black) units. Images were viewed using a $40 \times$ objective. Five images of digestive tubules were randomly taken from each duplicate section from each animal. All images for each cytochemical tests were captured in one session during which the microscope illumination (powered by a stabilized DC supply) and camera setting were kept constant. The digital image consisted of an 8 -bit, $320 \times 240$ matrix of picture elements (pixels), where each pixel consisted of a number between 0 and 255 representing the intensity of transmitted light (or gray level) at a point. Stored images were later analyzed to determine the average pixel density of the reaction products in each image. For images from each cytochemical reaction the lower threshold level is determined to separate the reaction products from the background and entered into the program. The program automatically produces the binary image and threshold picture from the original image (Fig. 2). From the threshold image, the program automatically calculated the average gray value of the image and reported and stored it in a separate file as the average pixel density of the image. A mean pixel density (gray scale intensity) was then derived for each duplicate section for each individual mussel. For each cytochemical test, intrabatch control slides were used at the time of staining and during subsequent automated image analysis (AIA). The repeated staining and analysis of tissue sections from the same mussels showed that the variation in pixel density of each of the cytochemical tests was $<6$ to $8 \%$. 
Fig. 2. Mytilus edulis. Threshold pictures of digestive gland tissue sections derived for automatic image analysis by subtracting the background using lower threshold values for each cytochemical reaction. Original images were taken with a color camera mounted on a light microscope. (A) Gray scale image showing normal $\beta$-N-acetyl hexosaminidase (NAH) activity in the lysosomes of mussels from Double Bluff; (B) enlarged lysosomes showing increased $\mathrm{NAH}$ activity in mussels from Eagle Harbor; (C) lipofuscin (LF) levels in mussels from Double Bluff; (D) enhanced LF level in mussels from City Waterway in Commencement Bay; (E) neutral lipid (NL) levels in mussels from Coupeville; $(F)$ increased NL level in mussels from Eagle Harbor. No. of pixels: average gray scale intensity of the image

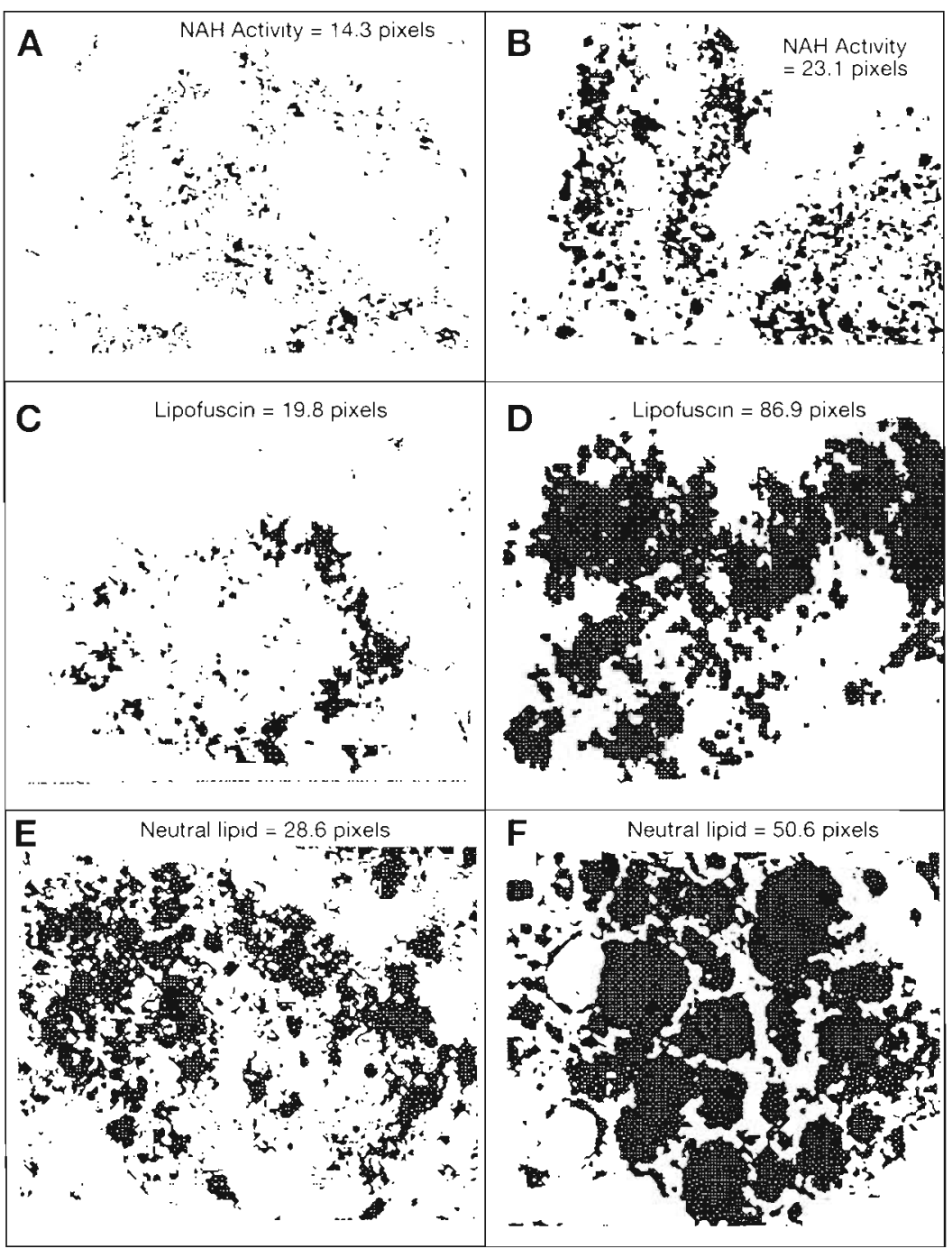

Statistical analyses. Differences in lysosomal responses, size, and gonadal indices of mussels among sites were tested by analysis of variance (ANOVA). Differences in lysosomal responses, size, and gonadal indices of mussels from all of the sites were assessed using Fisher's LSD Multiple Comparison Test. Generally, either there were no significant differences in the various parameters tested among mussels from the reference sites or mussels from the reference sites were more similar to each other than to mussels from the urbanassociated sites. Significant differences in lysosomal responses, size, and gonadal indices of mussels from all of the reference sites combined (combined reference) were then determined in comparison to mussels from each of the urban-associated sites using Dunnett's Multiple Comparison Test. This comparison provided information on differences in lysosomal and biological parameters between mussels from all of the reference sites and each of the urban-associated sites minimizing the potential confounding influence of unique abiotic and biotic factors unmeasured in this study. Non-linear regression analyses were used to evaluate the relationship between the mean lysosomal responses in the digestive cells of mussels with tissue burden of chemical contaminants. The non-linear regression algorithm, which obtains a least-squares estimate of the equation parameters (the Levenberg-Marquardt method) was applied using DeltaGraph (DeltaPoint, Inc., Monterey, CA, USA). A saturation exponential curve $\left(y=a e^{b x}\right)$ was used to model the relationships between biological effects and tissue-contaminant burden. Covariate analysis was used to evaluate the relationship between the shell length and somatic tissue weight of animals from minimally contaminated reference areas and mussels from the urban-associated sites. Findings were considered significant at $\alpha \leq 0.05$. 
Table 1 Temperature, salinity, and particulate organic matter concentration in seawater at sites in Puget Sound, Washington, USA, at the time of mussel sampling. September 21-24, 1992

\begin{tabular}{|lccc|}
\hline Site & $\begin{array}{c}\text { Temperature } \\
\left({ }^{\circ} \mathrm{C}\right)\end{array}$ & $\begin{array}{c}\text { Salinity } \\
\text { (ppt) }\end{array}$ & $\begin{array}{c}\text { POM } \\
\left(\mathrm{mg} \mathrm{l}^{-1}\right)\end{array}$ \\
\hline Eagle Harbor & 14.4 & 32 & 6.74 \\
City Waterway & 17.4 & 24.5 & 1.98 \\
Seacrest & 14.5 & 32.5 & 2.54 \\
Four Mile Rock & 14.1 & 32.1 & 8.19 \\
Sinclair Inlet & 14.9 & 31 & 2.81 \\
Oak Bay & 12.5 & 32.5 & 3.9 \\
Saltwater Park & 14.4 & 32 & 10.75 \\
Coupeville & 13 & 28.5 & 8.01 \\
Double Bluff & 12.5 & 30.5 & 3.46 \\
\hline
\end{tabular}

\section{RESULTS}

Environmental parameters such as water temperature, salinity and particulate organic matter at the 9 sites where mussels were sampled are shown in Table 1. Water temperatures ranged from 12.5 to $14.9^{\circ} \mathrm{C}$ at the time of sampling for most of the sites. This is consistent with water temperatures throughout Puget Sound which typically range from 11 to $14^{\circ} \mathrm{C}$ during this time of year (Collias et al. 1974). Water temperature in the City Waterway in Commencement Bay was $17.4^{\circ} \mathrm{C}$, the highest of all the sites tested. Salinity ranged from 28.5 to $32 \mathrm{ppt}$ for most of the sites tested. This is also consistent with salinity throughout Puget Sound which typically ranges from 28 to $31 \mathrm{ppt}$ throughout the year (Collias et al. 1974). Water salinity was 24.5 ppt in the City Waterway in Commencement Bay, the lowest of all sites tested. Particulate organic matter, a measure of the available food supply, ranged from a low of $1.98 \mathrm{mg} \mathrm{l}^{-1}$ in City Waterway to a high of $10.75 \mathrm{mg} \mathrm{l}^{-1}$ for water at Saltwater Park. Particulate organic matter ranged from 1.98 to $8.19 \mathrm{mg} \mathrm{l}^{-1}$ in waters from the urban-associated sites, whereas for the reference sites it similarly ranged from 3.46 to $10.75 \mathrm{mg} \mathrm{l}^{-1}$.

\section{Tissue contaminant burden}

Concentrations of organic contaminants and toxic and essential elements in the whole tissue of mussels (ng $\mathrm{g}^{-1}$ dry wt) from 9 Puget Sound sites are shown in Table 2. Tissue concentrations of total low-and highmolecular-weight PAHs, total PCBs, total DDTs and other pesticides were higher in mussels from the urban-associated sites (Eagle Harbor, City Waterway, Seacrest, Four Mile Rock and Sinclair Inlet) than for mussels from reference sites (Oak Bay, Saltwater Park, Coupeville and Double Bluff). Mussels from Eagle Harbor had the highest tissue concentration of low and high molecular weight PAHs (26 120 and $37490 \mathrm{ng} \mathrm{g}^{-1}$ dry wt respectively) whereas mussels from the reference sites had the lowest tissue concentrations of low and high molecular weight PAHs $\left(<90\right.$ and $<80 \mathrm{ng} \mathrm{g}^{-1}$ dry wt respectively). Similarly, mussels from the urban-associated sites had tissue concentration of total PCBs which ranged from 290 to $500 \mathrm{ng} \mathrm{g}^{-1}$ dry wt, whereas mussels from the reference sites had lower tissue concentration of PCBs ranging from 50 to $140 \mathrm{ng}$

Table 2. Mytilus edulis. Concentration of organic and metal contaminants in the whole tissue of (ng $g^{-1}$ dry tissue wt) sampled from Puget Sound, September 21-24, 1992. Samples were analyzed with GC/MS for polycyclic aromatic hydrocarbons and with GC/ECD for chlorinated hydrocarbons. Metals were analyzed using atomic absorption spectotroscopy after acid digestion. High molecular weight (HMW) PAHs: fluoranthene, pyrene, benz(a)anthracene, chrysene, benzofluoranthenes, benzo(a)pyrene, indeno( $1,2,3,-c, d)$ pyrene, dibenzo( $(a, h)$ anthracene, and benzo(g,h,i)perylene. Low molecular weight (LMW) PAHs: naphthalene, acenaphthylene, acenapthene, fluorene, phenanthrene, anthracene, and 2-methylnaphthalene. Total DDTs: DDT, DDE and DDD. Pesticides: aldrin, chlordane, dieldrin, heptachlor and lindane. See 'Methods' for additional detail

\begin{tabular}{|c|c|c|c|c|c|c|c|c|c|c|c|c|c|}
\hline \multirow[t]{2}{*}{ Site } & \multicolumn{2}{|c|}{$\begin{array}{c}\text { Polycyclic aromatic } \\
\text { hydrocarbons }\end{array}$} & \multicolumn{3}{|c|}{$\begin{array}{l}\text { Chlorinated } \\
\text { hydrocarbons }\end{array}$} & \multirow[b]{2}{*}{$\mathrm{Ag}$} & \multirow[b]{2}{*}{ As } & \multirow[b]{2}{*}{$\mathrm{Cd}$} & \multicolumn{2}{|c|}{ - Metals } & \multirow[b]{2}{*}{$\mathrm{Pb}$} & \multirow[b]{2}{*}{$\mathrm{Se}$} & \multirow[b]{2}{*}{$\mathrm{Zn}$} \\
\hline & HMW & LMW & PCBs & $\begin{array}{l}\text { Total } \\
\text { DDTs }\end{array}$ & $\begin{array}{l}\text { Other } \\
\text { pesticides }\end{array}$ & & & & $\mathrm{Cu}$ & $\mathrm{Hg}$ & & & \\
\hline Eagle Harbor & 37490 & 26120 & 400 & 21 & 16 & 14 & 3010 & 3450 & 5540 & 320 & 940 & 2360 & 168000 \\
\hline City Waterway & 5010 & 750 & 490 & 29 & 33 & 74 & 3550 & 4280 & 9610 & 115 & 11590 & 1760 & 451000 \\
\hline Seacrest & 1230 & 400 & 500 & 28 & 22 & 11 & 3340 & 5290 & 5280 & 330 & 1360 & 2340 & 201000 \\
\hline Four Mile Rock & 820 & 320 & 290 & 19 & 17 & 56 & 3670 & 4600 & 5060 & 65 & 1540 & 1710 & 197000 \\
\hline Sinclair Inlet & 120 & 100 & 180 & 15 & 11 & 108 & 2720 & 2790 & 4260 & 100 & 950 & 2080 & 150000 \\
\hline Oak Bay & 40 & 70 & 60 & 11 & 10 & 185 & 5380 & 5210 & 4200 & 96 & 550 & 2510 & 137000 \\
\hline Saltwater Park & 90 & 80 & 140 & 9 & 17 & 69 & 3070 & 3750 & 3310 & 195 & 550 & 1350 & 102000 \\
\hline Coupeville & 50 & 80 & 50 & 11 & 12 & 53 & 3210 & 3460 & 3070 & 25 & 860 & 1090 & 69000 \\
\hline Double Bluff & 50 & 70 & 110 & 11 & 11 & 209 & 3160 & 2370 & 4270 & 185 & 410 & 1880 & 106000 \\
\hline
\end{tabular}


$\mathrm{g}^{-1}$ dry wt. Tissue concentrations of silver, arsenic, cadmium and selenium were similar or lower in mussels from urban-associated sites compared to mussels from the reference sites. Tissue concentrations of copper, mercury, lead and zinc were generally higher in mussels from the urban-associated sites compared to mussels from the reference sites. Tissue concentrations of copper, zinc and lead were approximately 2 to 13 times higher in mussels from the City Waterway in Commencement Bay compared to the concentrations of these specific elements in mussels from the reference sites.

\section{Biological measurements}

The mean shell length, dry total tissue weight, dry somatic (total wt - gonad wt) tissue weight, and gonadal condition indices (GI) are shown in Table 3 . Mussels from the 4 most-contaminated sites of Eagle Harbor, City Waterway, Seacrest and Four Mile Rock were significantly smaller $(p \leq 0.05)$ in shell length and total and somatic tissue weight compared to mussels from all the reference sites (ANOVA, Dunnett's Multiple Comparison Test). Shell length and total and somatic tissue weight of mussels from Sinclair Inlet, the least contaminated of mussels from urban-associated sites, were similar to mussels from the reference sites. The relationship between shell length and somatic tissue weight are shown in Fig. 3. The relationship between somatic tissue weight and shell length of mussels from the urban-associated sites was found to be significantly different $(p \leq 0.05)$ from the relationship between shell length and somatic tissue weight of mussels from the reference sites sampled in Puget

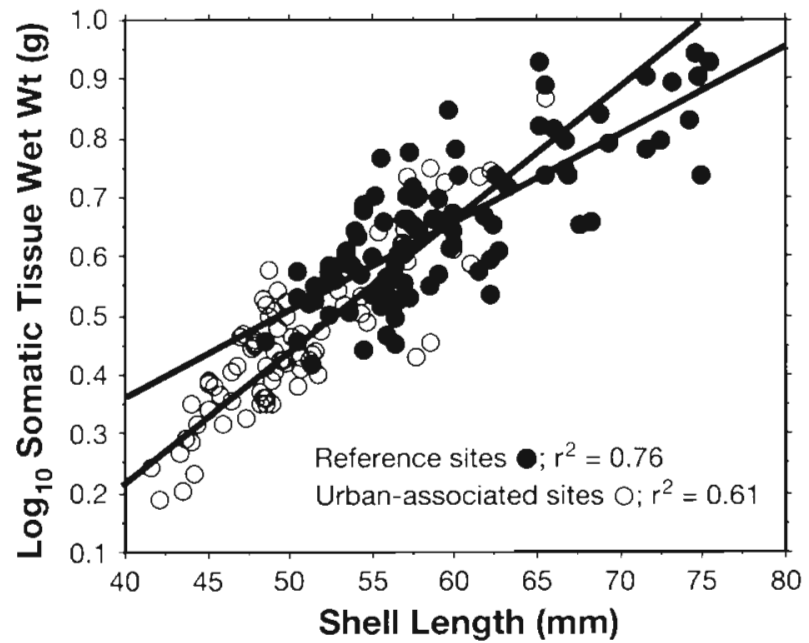

Fig. 3. Mytilus edulis. Relationship between somatic tissue weight and shell length of mussels from urban-associated and reference sites in Puget Sound

Sound. Tissue weight was lower for mussels from urban-associated than from reference sites in mussels of similar shell length. Significant differences in gonadal indices of mussels from all sites in Puget Sound were also observed (ANOVA, Fisher's LSD Comparison Test), however the combined GI of mussels from all reference sites was not significantly different $(p>0.05)$ than values for mussels from any of the urban-associated sites (Table 3). Gonadal indices for mussels from the urban-associated sites ranged from approximately 26 to $31 \%$. Similarly, GI of mussels from the reference sites ranged from 26 to $32 \%$ indicating that mussels from all the sites sampled were in a similar stage of gonadal development.

Table 3. Mytilus edulis. Biological measures of morphometric growth and gonadal index of mussels collected from urban and reference sites in Puget Sound. Means $\pm S D ; n=20$. Significantly $(p \leq 0.05)$ different than for mussels from all reference sites combined (ANOVA, Dunnetts' Multiple Comparison 1-tailed test)

\begin{tabular}{|c|c|c|c|c|}
\hline Site & $\begin{array}{l}\text { Shell length } \\
(\mathrm{mm})\end{array}$ & $\begin{array}{c}\text { Total tissue dry wt } \\
\text { (g) }\end{array}$ & $\begin{array}{l}\text { Somatic tissue dry wt } \\
\qquad(\mathrm{g})\end{array}$ & $\begin{array}{c}\text { Gonadal index } \\
(\%)\end{array}$ \\
\hline \multicolumn{5}{|l|}{ Urban } \\
\hline Eagle Harbor & $51.9 \pm 6.0$ & $1.04^{\circ} \pm 0.46$ & $0.71^{\circ} \pm 0.28$ & $30.7 \pm 5.1$ \\
\hline City Waterway & $50.1^{\circ} \pm 5.2$ & $0.75^{\circ} \pm 0.20$ & $0.55^{\circ} \pm 0.14$ & $26.2 \pm 4.9$ \\
\hline Seacrest & $47.9^{\circ} \pm 5.2$ & $0.76^{\circ} \pm 0.32$ & $0.50^{\circ} \pm 0.20$ & $31.4 \pm 4.2$ \\
\hline Four Mile Rock & $51.4^{\circ} \pm 4.0$ & $0.86^{\circ} \pm 0.21$ & $0.62^{*} \pm 0.15$ & $27.4 \pm 3.8$ \\
\hline Sinclair Inlet & $61.6 \pm 4.6$ & $1.39 \pm 0.39$ & $0.96 \pm 0.26$ & $30.1 \pm 4.2$ \\
\hline \multicolumn{5}{|l|}{ Reference } \\
\hline Oak Bay & $55.0 \pm 2.9$ & $1.00 \pm 0.22$ & $0.72 \pm 0.17$ & $26.1 \pm 3.3$ \\
\hline Saltwater Park & $56.7 \pm 5.2$ & $1.25 \pm 0.46$ & $0.87 \pm 0.30$ & $30.1 \pm 5.1$ \\
\hline Coupeville & $67.6 \pm 6.3$ & $1.80 \pm 0.41$ & $1.15 \pm 0.33$ & $32.2 \pm 4.8$ \\
\hline Double Bluff & $55.4 \pm 3.5$ & $1.33 \pm 0.33$ & $0.93 \pm 0.21$ & $29.4 \pm 3.6$ \\
\hline Combined reference & $58.6 \pm 6.9$ & $1.30 \pm 0.50$ & $0.92 \pm 0.30$ & $29.4 \pm 4.7$ \\
\hline
\end{tabular}


Table 4. Mytilus edulis. Lysosomal responses in digestive cells collected from Puget Sound using automated image analysis. NAH $\left(\beta-N\right.$-acetylhexosaminidase) activity is measured after a 5 min acid labilization period. Mean $\pm S D ; n=10 .{ }^{\circ}$ Significantly $(p \leq 0.05)$ different than for mussels from all reference sites combined (ANOVA, Dunnetts' Multiple Comparison 1-tailed test)

\begin{tabular}{|c|c|c|c|c|c|}
\hline Site & $\begin{array}{l}\text { Labilization period } \\
\text { (min) }\end{array}$ & $\begin{array}{c}\text { NAH latency } \\
(\%)\end{array}$ & $\begin{array}{l}\text { NAH activity } \\
\text { (pixel density) }\end{array}$ & $\begin{array}{l}\text { Neutral lipid } \\
\text { (pixel density) }\end{array}$ & $\begin{array}{c}\text { Lipofuscin } \\
\text { (pixel density) }\end{array}$ \\
\hline \multicolumn{6}{|l|}{ Urban } \\
\hline Eagle Harbor & $2.9^{\circ} \pm 1.5$ & $18.5^{\circ} \pm 9.3$ & $26.6^{\circ} \pm 10.3$ & $72.5^{\circ} \pm 5.6$ & $90.0^{\circ} \pm 9.5$ \\
\hline City Waterway & $5.5^{\circ} \pm 1.6$ & $30.8^{\circ} \pm 12.6$ & $30.9^{\circ} \pm 8.4$ & $69.9^{\circ} \pm 11.9$ & $103.7^{\circ} \pm 9.83$ \\
\hline Seacrest & $6.0^{\circ} \pm 2.1$ & $21.7^{\circ} \pm 10.4$ & $24.0 \pm 10.7$ & $86.1^{*} \pm 15.2$ & $82.2^{\circ} \pm 10.7$ \\
\hline Four Mile Rock & $8.0^{\circ} \pm 2.6$ & $34.0^{\circ} \pm 14.2$ & $22.4 \pm 8.9$ & $68.1^{\circ} \pm 8.5$ & $88.4^{\circ} \pm 16.0$ \\
\hline Sinclair Inlet & $8.5^{\circ} \pm 4.1$ & $33.9^{\circ} \pm 8.0$ & $22.2 \pm 5.4$ & $56.0 \pm 19.0$ & $82.5^{\circ} \pm 13.8$ \\
\hline \multicolumn{6}{|l|}{ Reference } \\
\hline Oak Bay & $18.0 \pm 2.6$ & $66.4 \pm 9.8$ & $20.2 \pm 4.9$ & $57.0 \pm 5.6$ & $57.8 \pm 16.5$ \\
\hline Saltwater Park & $16.5 \pm 2.4$ & $67.3 \pm 12.3$ & $16.6 \pm 8.3$ & $56.3 \pm 11.8$ & $66.8 \pm 8.6$ \\
\hline Coupeville & $14.0 \pm 3.9$ & $38.5 \pm 4.9$ & $17.1 \pm 3.4$ & $52.4 \pm 4.4$ & $43.9 \pm 12.1$ \\
\hline Double Bluff & $13.0 \pm 4.2$ & $43.1 \pm 9.0$ & $18.1 \pm 5.3$ & $55.0 \pm 18.8$ & $56.8 \pm 13.9$ \\
\hline Combined reference & $15.4 \pm 3.8$ & $53.8 \pm 16.1$ & $18.0 \pm 5.7$ & $55.2 \pm 11.3$ & $56.3 \pm 15.1$ \\
\hline
\end{tabular}

\section{Cytochemical measurements}

Lysosomal labilization period (lysosomal stability), $\%$ latency of NAH activity, NAH activity after 5 min of acid labilization and neutral lipid and lipofuscin content in the digestive cells of mussels from 9 sites in Puget Sound are summarized in Table 4. Lysosomal labilization period and lipofuscin content were significantly different (lower and higher, respectively, $\mathrm{p} \leq$ 0.05 ) in mussels from each of the urban-associated sites compared to mussels from all the reference sites (Combined Reference ANOVA, Dunnett's Multiple Comparison Test). The neutral lipid content and the \% latency of NAH activity were significantly different (higher and lower respectively, $p \leq 0.05$ ) in mussels from 4 of the urban-associated sites compared to mussels from all the reference sites. In contrast, NAH activity after $5 \mathrm{~min}$ of acid labilization was significantly higher ( $p \leq 0.05$ ) in mussels from only 2 of the 5 urbanassociated sites compared to mussels from all the reference sites.

In general, lysosomal labilization period, the \% latency of NAH activity, and lipofuscin and neutral lipid content were similar among mussels from the minimally contaminated reference sites and significantly different from mussels from the urban-associated sites (ANOVA, Fisher's LSD Comparison Test). Although significant differences in lysosomal NAH activity after $5 \mathrm{~min}$ of acid labilization were observed between mussels from all sites in Puget Sound and there was a general trend in higher NAH activity for mussels from some of the urban-associated sites compared to mussels from some of the reference sites, there was no consistent difference in NAH activity in mussels from the urban-associated sites compared to mussels from the reference sites. The relationship between lysosomal stability and \% latency of $\mathrm{NAH}$ activity was tested and a highly significant $(\mathrm{p}<0.001$, $r=0.86)$ positive correlation was also observed.

\section{Relationship between contaminant burden and biological and cytochemical measures}

There appears to be significant relationships between measures of anthropogenic exposure and biological effects in mussels from Puget Sound. For example, as the level of PAHs in mussel tissue increases, which is used as a measure of anthropogenic exposure, the mean lysosomal labilization period is significantly reduced (Fig. 4). Similarly, as the concentration of PCBs increases in mussel tissue, the total tissue dry weight of mussels from the most abundant size group of mussels at each site sampled is significantly reduced (Fig. 5). Similar relationships between biological effects and anthropogenic contaminants were observed with respect to the tissue burdens of some of the toxic metals, particularly with respect to tissue concentration of copper or zinc.

\section{DISCUSSION}

Results of this study demonstrate that mussels from urban-associated areas of Puget Sound exhibited significant changes in cytochemical and biological indices suggesting that these parameters may be useful indicators of contaminant-induced effects in natural populations of mussels. There have been only a few examples in field studies which have shown that biological indicators in mussels may reflect the effects of contaminant exposure (Moore et al. 1982, Bayne et al. 1988. 


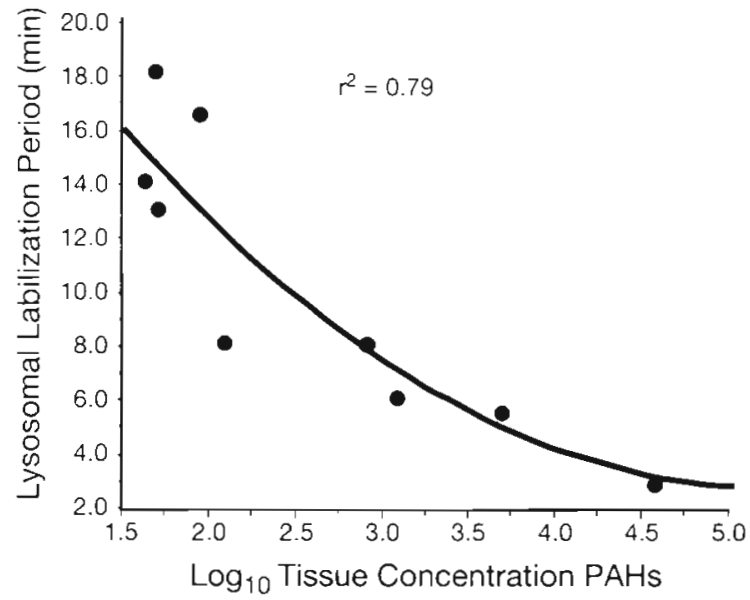

Fig. 4. Mytilus edulis, Relationship between lysosomal membrane stability and tissue concentration of high molecular weight PAHs of mussels from urban-associated and reference sites in Puget Sound

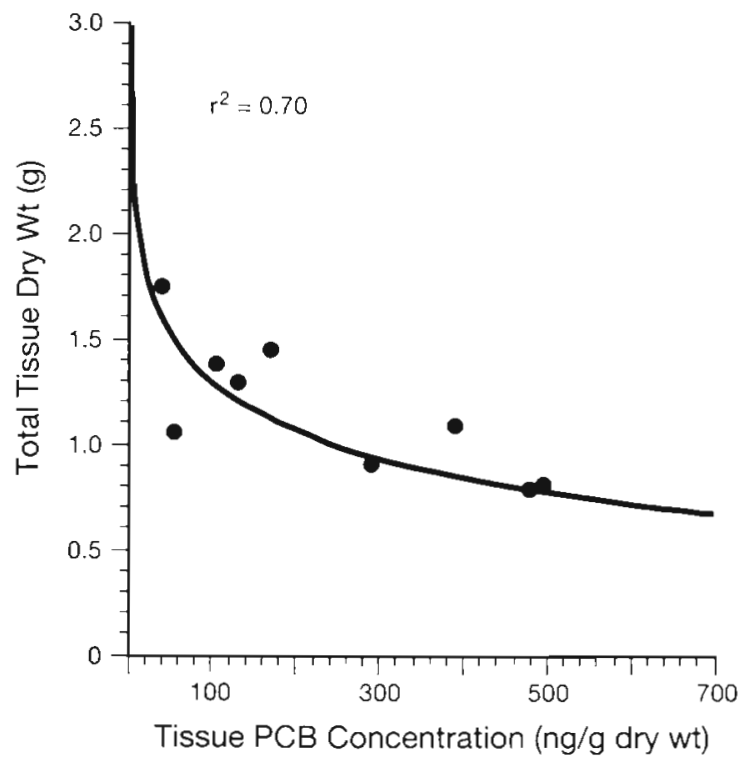

Fig. 5. Mytilus edulis. Relationship between somatic tissue weight and tissue concentration of PCBs of mussels from urban-associated and reference sites in Puget Sound

Regoli 1992). Laboratory studies have clearly shown that, in particular, lysosomal stability and function are affected by exposure to organic (Moore et al. 1985, Nott \& Moore 1987) and inorganic xenobiotic exposure (Viarengo et al. 1987, Regoli 1992). Further, mechanistic studies have shown the lysosomal stability in mussels is affected by the production of oxyradicals generated from contaminant exposure (Winston et al. 1991). In selected field studies that sampled mussels along a specific and known pollution gradient or after acute contaminant exposure such as after an oil spill, numerous biological indicators, including cytochemical measures of lysosomal function and scope for growth, showed significant positive correlation to measures of increased anthropogenic exposure (Moore et al. 1982, Bayne et al. 1988). There are, however, no studies that adequately validate the use of biological indicators in chronically exposed indigenous mussels as measures of contaminant-related biological effects. In our study, mussels were sampled from a variety of sites, thus randomizing the potential influence of environmental abiotic and biotic factors (for example, temperature and particulate organic matter) on the organism. As a result, any differences in the biology of the mussels from urban-associated and minimally contaminated reference areas that we identified were likely associated with xenobiotic exposure whereas similarities could not be associated with contaminant exposure. Based on the results of this study, lysosomal responses and morphometric measures of growth of mussels proved to be valid bioindicators of contaminant-related effects to mussels in the near-coastal environment.

The digestive gland in bivalve molluscs is a major site of accumulation of organic contaminants such as PAHs and toxic and essential elements (Fong 1976, Clement et al. 1980, Axiak et al. 1988). In the present study consistent pathological changes were observed in the lysosomes of the digestive cells of Mytilus edulis collected from urban-associated sites (Table 4, Fig. 2). Lysosomal stability and the \% latency of hydrolase activity in mussels from urban-associated sites were typically and significantly lower compared to lysosomal stability and the \% latency of hydrolase activity in mussels from reference areas. Laboratory studies have shown that PAHs such as phenanthrene and anthracene can induce dose-dependent lysosomal destabilization in the digestive cells of bivalves (Pipe \& Moore 1986, Nott \& Moore 1987, Axiak et al. 1988, Cajaraville et al. 1989, Winston et al. 1991, Viarengo et al. 1992). Ultrastructural studies have shown that phenanthrene, for example, can directly interact with the lipoprotein membrane of the secondary lysosomes and they are made discontinuous by membrane overlap (Nott \& Moore 1987). These alterations apparently destabilize the lysosomal membrane permitting greater access of substrate (Nott \& Moore 1987) and the consequent reduction in the \% latency of NAH activity as observed in the present study (Table 4). A significant relationship was observed between the lysosomal labilization period and \% latency of $\mathrm{NAH}$ related activity in this study, similar to what was reported by Moore (1991a) for $\mathcal{M}$. edulis.

Significantly elevated levels of neutral lipid and lipofuscin were also observed in the digestive cells of mussels collected from urban-associated areas (Table 4). 
Enhanced accumulation of neutral lipids and lipofuscin has reportedly been observed in secondary lysosomes and digestive cells of bivalves exposed to organic and toxic and essential elemental contaminants (Moore et al. 1982, 1985, Viarengo et al. 1987, Moore 1988, Krishnakumar et al. 1990, Regoli 1992). Capuzzo \& Leavitt (1988) and Leavitt et al. (1990) have similarly reported that an increase in the biochemically determined amount of neutral lipids with a concomitant decrease in polar lipid content occurs in the digestive gland cells of contaminant-exposed bivalves. The observed increase in neutral lipids could be described as a contaminant-induced lipidosis and is an indication of either increased synthesis or decreased utilization of neutral lipids (Kerr 1973, Moore 1991b). Lipofuscin is a product of peroxidative reactions on autophagocytosed lipoprotein membranes and its accumulation is associated with oxyradical reactions (Reddy et al. 1982, Sohal \& Wolfe 1986). Recent investigations showed that as a result of xenobiotic exposure oxyradicals are generated internally and externally to the lysosomal membrane, and the latter promotes destabilization of the lysosomal membrane (Winston et al 1991).

Lysosomal responses in the digestive cells of bivalve molluscs are not contaminant specific and can be induced by changes in other abiotic and biotic factors such as temperature, salinity and food availability (Pipe \& Moore 1985a, Moore et al. 1987). In the present study, mussels were collected from 9 areas within a short period of time $\left(\begin{array}{ll}4 & d\end{array}\right)$. Small variations were observed in temperature and salinity between these sites (Table 1) and thus these factors could not account for the observed differences in lysosomal function (Seed \& Suchanek 1992). In contrast, large variations were observed in the food availability, measured as POM at the various sites. However, optimum growth efficiency was reported in Mytilus edulis with a minimum ration level of $0.5 \mathrm{mg} \mathrm{l}^{-1}$ of POM (Widdows 1978). Particulate organic matter measured at all 9 sites were above the reported optimum level (Table 1) so the lack of available food cannot likely account for the observed differences in lysosomal function. Disseminated hemic neoplasia has also been reported to be endemic to bivalves, particularly to $M$. edulis in Puget Sound (Elston et al. 1992) and could affect lysosomal function However, we found in a preliminary study that equal prevalence (generally less than $30 \%$ ) of disseminated hemic neoplasia occur in mussels from all sites sampled in this study and thus could not account for differences in lysosomal function (Krishnakumar pers. obs.). Additionally, the reproductive cycle of the bivalves is also known to influence lysosomal function (Moore 1991a). However, in the present study, mussels collected from all sites were in a similar gametogenic spawning phase and no significant difference was observed in the gonadal indices of mussels collected from the urban-associated sites compared to the mussels from the reference areas (Table 3 ).

In this study, AIA was effectively used to measure the lysosomal responses in the digestive celis of mussels. The results show that AIA is a very efficient and reliable technique for analysis of samples collected from a number of sites (Table 4). The numerical representation of the binary images allowed us not only to define the quantitative nature and the reproducibility of the measurement of lysosomal degradation but also to apply appropriate statistical methods to the detection of small differences (Bartel \& Weid 1981). Another useful application of AIA is the visual demonstration of images with the use of pseudocolor assigned to critical gray levels. Pseudocolor in AIA allows easier discrimination and differentiation of the distribution and texture of various structural features and identification of chemical products in the sample. Image analysis is also a potentially useful tool for monitoring programs as images can be stored for future comparison and statistical analysis. The cytochemical measurement of lysosomal responses combined with AIA has the potential to be used as a sensitive, accurate, and rapid technique for assessing evidence of biological alteration of marine organisms due to contaminant exposure.

The results of biological measurements show that mussels are generally smaller in size (both shell size and tissue weights) and that somatic tissue weight relative to shell size was lower in specimens from urbanassociated sites compared to mussels from the reference sites (Table 3). A similar reduction in average size and tissue weight relative to shell size was observed in mussels from a monthly field survey of 6 of the same sites used in this study in the previous 2 yr (Casillas pers. obs.). These findings are consistent with other studies which report a general reduction in the scope for growth of mussels acutely exposed to contaminants or chronically exposed to contaminants along known pollution gradients (Widdows \& Johnson 1988, Widdows et al. 1990). In transplant studies in which mussels are deployed along known pollution gradients, a reduction in the scope for growth has often been related to a reduction in the actual growth of mussels (Martin et al. 1984, Salazar \& Salazar 1991, Veldhuizen-Tsoerkan et al. 1991). In transplantation studies, true estimates on the effects of contaminants on growth can be assessed since initial and final morphometric measures of growth can be made. However, in chronically exposed indigenous populations of mussels, true estimates of growth are difficult to obtain since growth is a time-related function. However, a reduction in the scope for growth of chronically exposed mussels should result in a reduction of the morphometric measures that are associated with 
growth, such as shell size, tissue weight and relationships between tissue weights and shell size (Seed \& Suchanek 1992). In fact, this was observed in our study; mussels from urban-associated areas showed significant reductions in many morphometric measures that are a function of growth (smaller shell length, tissue weight, ratio of tissue weight to shell length) compared to mussels from the reference areas. Although other abiotic and biotic factors could confound our interpretation, the use of a wide diversity of site types and locations likely reduces this possibility and minimizes the influence of factors such as water currents, salinity, temperature, food availability, time of spawning, and larval settlement period on the outcome of growth. It may also be important to recognize that mussels from urban-associated sites (Table 2) were likely to be exposed chronically to various contaminants. If the bioenergetic estimates of the effects of contaminants on growth are correct, a decrease in available size of the most abundant population should be apparent. In our study, we in fact observed smaller specimens from these urban-associated areas. From our field observations it also appeared that mussels in the urban-associated areas exhibited a lower population density and restricted distribution compared to the population density and distribution of mussels from reference areas, indicating possibly an increased stress on mussel populations from these urban-associated sites.

The possibility that contaminants in tissues could be related to impaired lysosomal stability, accumulation of lipofuscin and neutral lipids in the digestive cells, and decreased morphometric measures of growth was suggested by correlations between tissue PAH and PCB concentrations and lysosomal membrane stability and tissue weights (Figs. 4 \& 5). Experimental and field results of ultrastructural, cytochemical and morphometric studies showed that organic contaminants such as PAHs can in fact induce profound alterations in both structure and function of lysosomes in the digestive cells of bivalve molluscs (Bayne et al. 1988, Bayne 1989, Moore 1991b). Other investigators have reported positive relationships between selected pathological measures of impairment (hepatic lesions) in fish from Puget Sound and measures of contaminant exposure (e.g. fluorescent aromatic compounds in bile) (Krahn et al. 1986) as a demonstration of possible causal links between contaminant exposure and biological effects. Consequently, the consistent pathological changes observed in the present study in the lysosomal system of Mytilus edulis collected from urban-associated sites in Puget Sound could be attributed to the high tissue concentrations of contaminants, particularly organic contaminants, although some toxic elements such as copper and zinc could be involved as well. The above pathological changes in the digestive cells of mussels could result from: (1) a direct interaction of contaminants with lysosomal membranes, (2) biotransformation of organic contaminants into more cytotoxic products and (3) oxyradicals generated within and outside the lysosomal membrane as a result of redoxcycling of organic contaminants (Anderson 1985, Stegeman 1985, Nott \& Moore 1987, Varanasi et al. 1987, Kurelec et al. 1988, Livingstone et al. 1989, Winston et al. 1991). Although tissue burdens of PAHs, PCBs, and selected. toxic metals in mussels were significantly correlated with impaired lysosomal function, detoxification enzyme activity (Krishnakumar unpubl. data), and tissue weights, at this point we cannot determine the extent to which different classes of contaminants contribute to the observed effects, because of contaminant covarying co-occurrence in mussel tissues. However, it is reasonable to apply correlations as used in this study to link tissue contaminant burdens and biological effects. Further studies will be needed to determine which classes of contaminants in tissues are responsible for impaired function of the digestive cells and reduced growth of mussels.

In conclusion, natural populations of mussels from urban-associated areas of Puget Sound were shown to exhibit cytochemically measured impaired lysosomal stability, accumulation of lipofuscin and neutral lipids in the digestive cells, and evidence of reduced growth. The use of automatic image analysis significantly enhanced our ability to quantify the cytochemically measured responses in mussels allowing a more rapid, objective, and reliable measure of the effects of contaminants on cellular structures and content. Relationships between tissue contaminant burden and subsequent biological effects provide evidence of linkages between anthropogenic contaminants, subcellular and cellular events, and significant biological effects. The relationship between lysosomal stability, lipofuscin, and neutral lipid content and anthropogenic contaminant burden suggests that these cytochemically derived measures of subcellular and cellular events could be used as biomarkers of contaminant exposure and cell injury in mussels. We recommend that biological measures of effects of contaminants in bivalves be incorporated into programs that monitor the quality of the near coastal environment in conjunction with measures of tissue contaminant burden.

Acknowledgements. P.K.K. is thankful to the Department of Biotechnology, Government of India, New Delhi, for awarding a 'Biotechnology Overseas Associateship' for conducting this study. The authors thank the following members of the Environmental Conservation Division: Dave Misitano, Robert G. Snider and Steve Eddy for the help in sample collection; Mark Myers for helpful suggestions in tissue processing; and Dr Sin-Lam Chan, Don Brown, and Dr Jim Meador for over- 
seeing timely completion and assuring quality control. of chemical analyses of the mussel tissue samples. Dr Jim Meador provided many thoughtful comments in his critical review of the manuscript. These studies were partially supported by the NOAA Coastal Ocean Program Office of Ocean Resources Conservation and Assessment (NOAA, National Ocean Service), as part of the National Status and Trends Program.

\section{LITERATURE CITED}

Anderson, R. S. (1985). Metabolism of a model environmental carcinogen by bivalve molluscs. Mar. environ. Res. 17: $137-140$

Axiak, V., George, J. J., Moore, M. N. (1988). Petroleum hydrocarbons in the marine bivalve Venus verrucosa: accumulation and cellular responses. Mar. Biol. 97 : $225-230$

Bancroft, J. D. (1967). An introduction to histochemical technique. Butterworths, London

Bartels, P. H., Weid, G. L. (1981). Automated image analysis in clinical pathology. Am. J. clin. Pathol. 75 (suppl): 489-493

Bayne, B. L. (1989). Measuring the biological effect of pollution: the mussel watch approach. Wat. Sci. Tech. 21: $1089-1100$

Bayne, B. L., Clarke, K. R., Gray, G. S. (1988). Biological effects of pollutants: the results of a practical workshop. Mar. Ecol. Prog. Ser. 46:1-5

Bitensky, L., Butcher, R. S., Chayen, J. (1973). Quantitative cytochemistry in the study of lysosomal function. In: Dingle, J. T. (ed.) Lysosomes in biology and pathology, Vol. 3 Elsevier, Amsterdam, p. 465-510

Cajaraville, M. P., Marigomez, J. A., Angulo, E. (1989). A stereological survey of lysosomal structure alterations in Littorina littorea exposed to 1-naphtol. Comp. Biochem. Physiol. 93C: $231-237$

Capuzzo, J. M., Leavitt, D. F. (1988). Lipid composition of the digestive glands of Mytilus edulis and Carcinus maenas in responses to pollutant gradients. Mar. Ecol. Prog. Ser. 46: $139-145$

Clement, L. E., Stekoll, M. S., Shaw, D. G. (1980). Accumulation, fractionation and release of oil by the intertidal clam Macoma balthica. Mar. Biol 57: 41-50

Collias, E. E., McGary, N., Barnes, C. A. (1974). Atlas of physical and chemical properties of Puget Sound and its approaches. University of Washington Press, Seattle

Dardick, I., Payne, C. M. (1992). Rationale and potential for image anlysis in histopathology: an overview. Ultrastruct. Pathol. 16: $97-98$

Elston, R. A., Moore, J. D., Brooks, K. (1992). Disseminated neoplasia of bivalve molluscs. Rev. aquat. Sci. 6: 405-466

Fong, W. C. (1976). Uptake and retention of Kuwait crude oil and its effects on oxygen uptake by the soft-shell clam, Mya arenaria. J. Fish. Res. Bd Can. 33: 2774-2780

Gray, J. S. (1992). Biological and ecological effects of marine pollutants and their detection. Mar. Pollut. Bull. 25: 48-50

Hader, D. P. (1992). Image analysis in biology. CRC Press, London

Hawkins, H. K. (1980). Reactions of lysosomes to cell injury. In: Trump, B. F., Arstila, A. V. (ed.) Pathobiology of cell membranes, Vol. 2. Academic Press, New York, p $252-285$

Henderson, B. (1983). The application of quantitative cytochemistry to the study of diseases of the connective tissue. Prog. Histochem. Cytochem. 15: 1-86

Kerr, J. F. R. (1973). Some lysosome functions in liver cells reacting to sublethal injury. In: Dingle, J. T (ed.) Lysosomes in biology and pathology, Vol. 3. Elsevier, Amsterdam, p. 365-394

Krahn, M. M., Moore, L. K., Bogar, R. G., Wigrens, C. A., Chan, S. L., Brown, D. W. (1988). High performance liquid chromatographic methods for isolating organic contaminants from tissue and sediment extracts. J. Chromatogr. 437: $161-175$

Krahn, M. M., Rhodes, L. D. Myers, M. S., Moore, L. K. MacLeod, W. D., Malins, D. C. (1986). Association between metabolites of aromatic compounds in bile and the occurrence of hepatic lesions in English sole (Parophry vetulus) from Puget Sound, Washington. Arch. environ. Contam. Toxicol. 15: 61-67

Krishnakumar, P. K., Asokan, P. K., Pillai, V. K. (1990). Physiological and cellular responses to copper and mercury in the green mussel Perna viridis (Linnaeus). Aquat. Toxicol. 18: $163-174$

Kurelec, B., Chako, M., Gupta, R. C. (1988). Post labelling analysis of carcinogen-DNA adducts in mussel, Mytilus galloprovincialis. Mar. environ. Res. 24: 317-320

Leavitt, D. F., Lancaster, M. A., Lancaster, A. S., Capuzzo, J. M. (1990). Changes in the biochemical composition of a subtropical bivalve, Arca zebra, in response to contaminant gradients in Bermuda. J. exp. mar. Biol. Ecol. 138: $85-98$

Livingstone, D. R. (1991). Organic xenobiotics metabolism in marine invertebrates. In: Gilles, R. (ed.) Advances in comparative and environmental physiology. Springer-Verlag, Berlin, p. 45-185

Livingstone, D. R., Kirchin, M. A., Wiseman, A. (1989). Cytochrome P-450 and oxidative metabolism in molluscs. Xenobiotica 19: 1041-1062

Lowe, D. M., Moore, M. N., Clarke, K. E. (1981). Effect oil on digestive cells in mussels: quantitative alterations in cellular and lysosomal structure. Aquat. Toxicol. 1: 213-226

MacLeod, W. D. Jr, Brown, D. W., Friedman, A. J., Burrows, D. G., Maynes, O., Pearce, R. W., Wigrens, C. A., Bogar, R. G. (1985). Standard analytical procedures of the NOAA National Analytical Facility: extractable toxic organic compounds. NOAA Technical Memorandum NMFS/F/ NWC-92 (PB 86-147873). National Technical Information Service, Springfield, VA

Martin, M., Ichikawa, G., Goetzl, J., Reges, M. D. L., Stephenson, M. D. (1984). Relationship between physiological stress and trace toxic substances in the bay mussel Mytilus edulis from San Fransisco Bay, California. Mar. environ. Res. 11: 91-110

Moore, M. N. (1988). Cytochemical responses of the lysosomal system and NADPH-ferrihemoprotein reductase in molluscan digestive cells to environmental and experimental exposure to xenobiotics. Mar. Ecol. Prog. Ser. 46: $81-89$

Moore, M. N. (1991a). Lysosomal changes in the response of molluscan hepatopancreatic cells to extracellular signals. Histochem. J. 23: 495-500

Moore, M. N. (1991b). Environmental distress signals: cellular reactions to marine pollution. In: Graumann, W., Drukker, $J$. (eds.) Histo- and cytochemistry as a tool in environmental toxicology. Prog. Histochem. Cytochem. 23: 2-19

Moore, M. N., Clarke, K. R. (1982). Use of microstereology and quantitative cytochemistry to determine the effect of crude oil-derived aromatic hydrocarbons on lysosomal structure and function in a marine bivalve mollusc, Mytilus edulis. Histochem. J. 14:713-718

Moore, M. N., Livingstone, D. R., Widdows, J., Lowe, D. M., Pipe, R. K. (1987). Molecular, cellular, and physiological 
effects of oil-derived hydrocarbons on moliuscs and their use in impact assessment. Phil. Trans. R. Soc. Lond. B316: $603-623$

Moore, M. N., Mayernick, J. A., Giam, C. S. (1985). Lysosomal responses to a polynuclear aromatic hydrocarbon in marine snail: effects of exposure to phenanthrene and recovery. Mar. environ. Res. 17: 230-233

Moore, M. N., Pipe, R. K., Farrar, S. V. (1982). Lysosomal and microsomal responses to environmental factors in $L$. Littorea from Sullom Voe. Mar. Pollut. Bull. 13: 340-345

NOAA (National Oceanic and Atmospheric Administration) (1989). National Status and Trends Program for Manne Enviromental Quality: a summary of data on tissue concentration from the first three years (1986-1988) of the Mussel Watch project. NOAA Tech. Memo. NOS/OMA-49

Nott, J. A., Moore, M. N. (1987). Effects of polycyclic aromatic hydrocarbons on molluscan lysosomes and endoplasmic reticulum. Histochem. J. 19: 357-368

O'Conner, T. (1992). Recent trends in coastal environmental quality: results from the first five years of the NOAA Mussel Watch Project. NOAA, Department of Commerce, Silver Spring, MD

Pearse, A. G. E. (1972). Histochemistry, theoretical and applied, Vol. 2. Churchill-Livingstone, London

Robisch, P. A., Clark, R. C. (1993). Sample preparation and analyses of trace metals by atomic absorption spectroscopy. In: Lauenstein, G. G., Cantillo, A. Y (eds.) Sampling and analytical methods of the National Status and Trends Program National Benthic Surveillance Program and Mussel Watch Project 1984-1992, Vol. Ill. Comprehensive description of elemental analytical methods. NOAA Tech. Memo. NOS ORCA 71, p. 111-150

Pipe, R. K., Moore, M. N. (1985). Ultrastructural changes in the lysosomal vacuolar system in digestive cells of $M$. edulis as a response to increased salinity. Mar. Biol. 87: $157-163$

Pipe, R. K., Moore, M. N. (1986). An ultrastructural study on the effect of phenanthrene on lysosomal membrane and distribution of the lysosomal enzyme b-glucuronidase in the digestive cells of the periwinkle L. littorea. Aquat. Toxicol. 8: 65-76

Reddy, J. K., Lalwani, N. D., Reddy, M. K., Qureshi, S. A. (1982). Excessive accumulation of autofluorescent lipofuscin in the liver during hepatocarcenogenesis by methyl clofenapate and other hypolipidamic peroxisome proliferators. Cancer Res. 42: 259-266

Regoli, F. (1992). Lysosomal responses as a sensitive stress index in biomonitoring heavy metal pollution. Mar Ecol. Prog. Ser. 84: 63-69

Salazar, M. H., Salazar, S. M. (1991). Assessing site specific effects of TBT contamination with mussel growth rates. Mar. environ. Res. 32: 131-150

Seed, R., Suchanek, T. H. (1992). Population and community ecology of Mytilus. In: Gosling, E. (ed.). The mussel Myti-

This article was submitted to the editor lus: ecology, physiology, genetics, and culture. Elsevier New York, p. 87-169

Sohal, R. S., Wolfe, L. S. (1986). Lipofuscin: characteristics and significance. In: Swaab, D. F., Fliers, E., Mirmiran, M., Van Gool, W. A., Van Harren, F. (eds.) Progress in brain research, Vol. 70. Elsevier Science Publishers, Amsterdam, p. 171-183

Stegemann, J. J. (1985). Benzo(a)pyrene oxidation and microsomal enzyme activity in the mussel ( $M$. edulis) and other bivalve mollusc species from the Western North Atlantic Mar. Biol. 89: 21-30

Stein, J. E., Collier, T. K., Reichert, W. L., Casillas, E., Hom, T. Varanasi, U. (1992). Bioindicators of contaminant exposure and sublethal effects: studies with benthic fish in Puget Sound, Washington. Environ. Toxicol. Chem. 11: $701-714$

VanNoorden, C. J. F. (1991). Assessment of lysosomal function by quantitative histochemical and cytochemical methods. Histo. Chem. J. 23: 429-435

Varanasi, U., Stein, J. E., Nishimoto, M., Reichert, W. L., Collier, T. K. (1987). Chemical carcenogenesis in feral fish: Uptake, activation and detoxification of organic xenobiotics. Environ. Health Prospect. 71: 155-170

Veldhuizen-Tsoerkan, M. B., Holwerda, D. A., deBont, A. M. T., Smaal, A. C., Zandee, D. I. (1991). A field study on stress indices in the sea mussel, Mytilus edulis: application of the 'stress approach' in biomonitoring. Arch. environ. Contam. Toxicol. 21: 497-504

Viarengo, A., Moore, M. N., Mancinelli, G., Mazzucotelli, A. Pipe, R. K., Farrar, S. V. (1987). Metallothioneins and lysosomes in metal toxicity and homeostasis in marine mussels: the effects of cadmium in the presence and absence of phenanthrene. Mar. Biol. 94: 251-257

Viarengo, A., Moore, M. N., Pertica, M., Mancinelli, G., Accomando, R. (1992). A simple procedure for evaluating the protein degradation rate in mussel $(M$. galloprovincialis Lam.) tissues and its application in a study of phenanthrene effects on protein catabolism. Comp. Biochem. Physiol. 103B: 27-32

Widdows, J. (1978). Physiological indices of stress in $M$. edulis. J. mar. biol. Ass. U.K. 58: 125-142

Widdows, J., Johnson, D. (1988). Physiological energetics of Mytilus edulis: scope for growth. Mar. Ecol. Prog. Ser. 46 $113-121$

Widdows, J., Burns, K. A, Menon, N. R., Page, D. S., Soria, S (1990). Measurement of physiological energetics (scope for growth) and chemical contaminants in mussels (Arca zebra) transplanted along a contamination gradient in Bermuda. J. exp. mar. Biol. Ecol. 138: 99-117

Winston, G. W., Moore. M. N., Straatsburg I., Kirchin, M. A. (1991). Decreased stability of digestive gland lysosomes from the common mussel $M$. edulis $\mathrm{L}$. by in vitro generation generation of oxygen-free radicals. Arch. environ Contam. Toxicol. 21: 401-408

Manuscript first received: June 10, 1993

Revised version accepted: January 20,1994 